\title{
Neoliberal hegemony and the territorial re-configuration of public space in Mexico City
}

\author{
Carla Filipe Narciso \\ Centro de Investigaciones en Arquitectura, Urbanismo y Paisaje, Facultad de Arquitectura, \\ Universidad Nacional Autonoma de México. Distrito Federal, Mexico \\ E-mail: carla-narciso@iol.pt
}

\begin{abstract}
Sustainability, ecological modernization, citizen participation, public space and rights are concepts that have acquired great importance in international political discourses and that have figured in indicators, guidelines, programs and policies, at national level, giving rise to a urban planning from administrative units or "zoning", which instead of showing the different structures, forms and functions of cities as a whole, what has generated is a fragmentation of urban space. In a certain way, the implosion of these themes shows the success of capitalism in a period of neoliberal hegemony, since it becomes a smokescreen to hide the class differences superimposed on global discourses of modernization and development, as well as the transformation of natural resources in products, the capitalization of nature and the transformation of politics into management. The text seeks to reflect on the territorial configuration of public space in the light of emerging urban policies and programs in a neoliberal geopolitical context based on two axes of analysis: in the first analyze the neoliberal imposition models on how to construct public space and in the second will analyze the institutional bases, programs and policies of intervention highlighting their objectives, limitations and contradictions that help to understand the material and immaterial forms that the public space adopts at different scales in Mexico City through of the socio-territorial relations that are constructed in a process of mutual reciprocity.
\end{abstract}

Keywords: public space, neoliberal hegemony, México City, territorial configuration, urban police.

\section{Introduction}

In the last decades, globalization and neoliberalism have promoted to a urbanism that adapts the construction of the city and new urban "forms" to the compression of spacetime driven by late capitalism through the acceleration of economic processes, increasing commodification of cultural symbols and the very transformation of the subjective experience of space-time (Harvey, 1990). In this historical context began to question the functions of urban spaces under the argument that the space of places, typical of modern urbanism, lost prominence and importance in front of the space of flows that pushed the postmodern urbanism, where everything moves and Nothing is fixed (Narciso, 2014). It begins to transnationalize the forms of city making based on models imposed by the hegemonic economy of the capitalist countries (Parnreiter, 2015), implicit in ideological discourses "that shifts the economic and territorial decisions of the state apparatuses to the centers of management of the Transnational capital, regional agreements, or the anarchic terrain of free competition between large corporations, oligopolies or multinational economic agreements "(Pradilla, 2009: 118). This mobility of policies and programs of urban intervention have generated important changes in the processes of reproduction and 
recomposition of the social geographies of the city, especially from a re-invention of public space and how this became an element of Socio-spatial transformation, which conceals all the asymmetries of neoliberal policies of interference. The result was the loss of spaces of coexistence, sociability, encounter, recreation and identity and, consequently, greater segregation and social exclusion as well as a sharper division and separation of class and of different social groups. In this line of thought, the words of order and prominence are expressed in renewal, restructuring, regeneration and urban retraining, since they were considered as hegemonic political instruments and ideas that contribute to social cohesion and the integration of excluded or vulnerable sectors, Capable of counteracting the uncontrollable fluidity and territorial uprooting of late capitalism. Making a city becomes an electoral project, a form of social legitimacy of political powers and an ideological product and discourse of social control in which urban projects in different geographic latitudes reproduce converging in them the immediate objective of attracting new Capital, both social and economic, where public space gains special prominence, becoming part of any political agenda of both federal, state and local governments. Thus, the present work seeks to reflect on the socio-spatial construction of public space based on one side of the different neoliberal narratives expressed in it and on the other as expressed in a particular partisan political context of Mexico City. However, and as Brenner, Peck and Theodore (2009) well mentions, "neoliberalism", especially in the broad field of heterodox political economy, seems to have become a concept of rogue - promiscuously omnipresent, but inconsistently defined, empirically imprecise And frequently disputed. It is therefore important to define the basis of the approach from the neoliberal paradigm in which the relationship of its characteristic economic process and public space is determined through two main axes: the geopolitical reproduction of ideologies oriented to the global market; And the institutionalization of transnational frameworks of social reproduction through political discourses that are territorialized in public space.

\section{The Neoliberal Imposition Models in the Constructed of Public Space}

Cities from the 1970s became the main nodes or strategic axes of neoliberal policies for the reconversion of contemporary politicaleconomic space, in the reform of projects that have had an impact on different territorial scales, defined by the contexts Local, institutional, political regimes, regulatory practices and geopolitical influences. As a basis for overcoming the crisis, the State takes a much more authoritarian stance and determines radical changes in the policies of the bourgeoisie and the states, which has produced significant changes in their territorial, regional and urban structures, and in the nature and magnitude of the contradictions they express (...) (Pradilla, 2009: 91). Thus, today's cities are embedded in a highly uncertain geo-economic environment, characterized by monetary chaos, speculative movements of financial capital, global localization strategies by large transnational corporations, and rapid intensification of competition between interlocutors (Swyngedouw, 1992). In the context of this deepening of the "global-local disorder" (Peck and Tickell, 1994), most local governments have been limited - to some extent, regardless of their political orientation and national context - to adjust to the levels High levels of economic uncertainty through participation in short-term forms of interspatial competition, spot marketing and regulatory undercutting to attract investment and jobs (Leitner and Sheppard 1998). Meanwhile, the reduction of national welfare state systems and national intergovernmental systems has also imposed new fiscal constraints on cities, leading to significant budget cuts during a period when local social problems and conflicts intensified Together with rapid economic restructuring. We point out that, throughout the developed capitalist world, cities have become strategically central places for the irregular progress of neoliberal restructuring projects, for their constitution and trend resistance. Cities define some of the spaces in which 
neoliberalism takes root, a geographically variable project, but interconnected translocally. It is also in the urban context that the repeated failure of neoliberal policies and some sporadic resistance to them occurs, which also makes visible certain potential limits of the neoliberal project (Brenner, Peck, Theodore, 2009). The central location of cities in the Fordist-Keynesian systems of production and reproduction define them as key (if not 'white') arena for neoliberal dismantling strategies, but their strategic significance as a loci of innovation and growth, and as zones of Delegated governance and local institutional experimentation, also place them at the forefront of neoliberal progress. (Brenner, Peck, Theodore, 2009). The concept of space becomes so imperative, especially to think the current state of architecture and urbanism, because as disciplines of urban space and the city are key to understand the development of an economic model based on maximum reduction of Intervention of the State and the free market and in which "urban infrastructures are necessary for the accumulation and neoliberal regulation, even when in the process they are simultaneously undermined and devalued; Cities are placed on the frontiers of the formation of neoliberal policies, while at the same time they are places of concerted resistance to neoliberalization "(Brenner et al., 2009: 7). Thus neoliberal programs have been internalized in urban policies and in the way the urban space is constructed, mobilizing spaces of the city for both market-oriented economic growth and consumption practices of the elites, while ensuring Order and control of excluded populations (idem). Thus, public space becomes part of discursive narratives that seek to conceal reality through its ideological character and that everything seeks to coordinate.

\section{Material and Immaterial Forms of the Public Space in Mexico City}

Over the last three decades, cities have become strategically decisive arenas where neo-liberal forms of creative destruction have been deployed. The preponderance of cities in the Fordist-Keynesian systems of production and reproduction has influenced its definition as a key (if not "white") arena for neoliberal dismantling strategies, but its strategic significance as a loci of innovation and growth, and Areas of delegated governance and local institutional experimentation, also place them at the forefront of neoliberal advancement (Brenner et al, 2009). In this context, local governments have adjusted (with some imposition or by deliberation) to internationalcut policies, and have incorporated some territorial relations to strengthen local economies by means of a "shock treatment" of deregulation, privatization, Liberalization and greater fiscal austerity. Thus cities (from different geographic latitudes) have become territories and "institutional laboratories for various experiments in neoliberal policies,
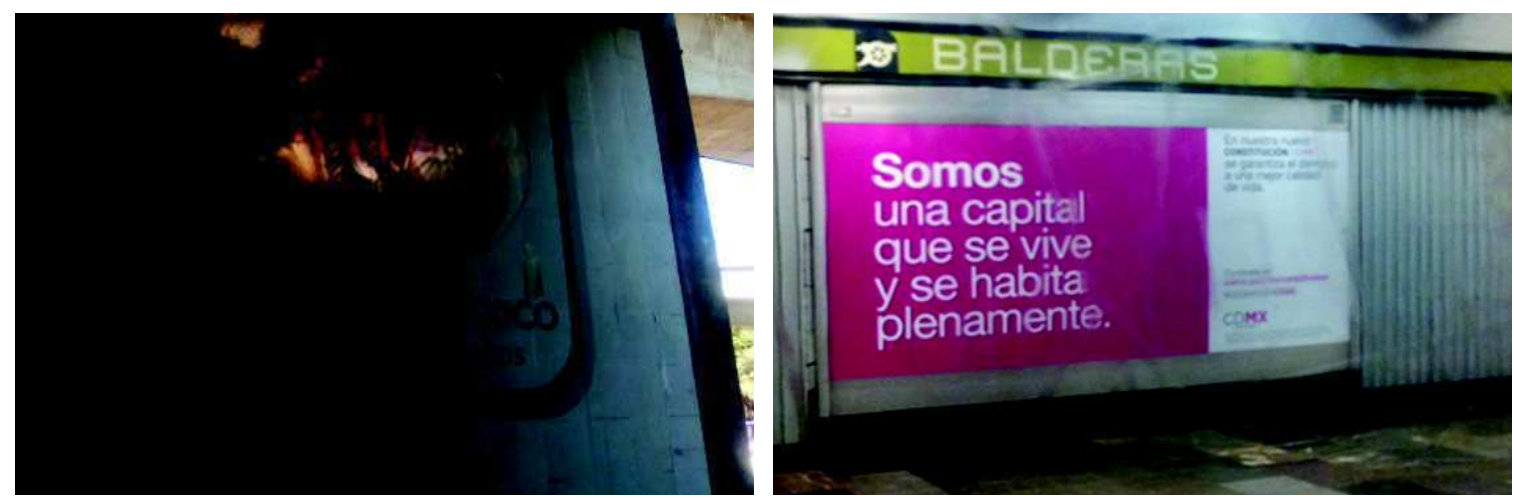

Figure 1.

a. (left) New slogan of the City that emphasizes the idea of democratic citizen participation Deciding Together. Source: Author. b. (right) The new image of the city is spread throughout all areas of the city especially in those with greater popular influx such as the Balderas metro. Source: Fernanda García 
such as territorial marketing, the creation of business zones, the reduction of local taxes, the promotion of public partnerships -private and new forms of local promotion "(idem). In Mexico City, this possibility of reproduction of urban space is spatialized and legitimized through urban policies that demand a universalist discourse, respect for human rights, collective interest, democracy and plurality. However, this strategy is also part of the government's inability to resolve the different conflicts and problems that arise due to different governmental and private interests, under the current institutional system; That is, where there is no democratic participation, where there is a lack of transparency in decision-making processes, where the media are highly efficient in concealing and deterring real problems and where corruption reaches exaggerated levels. Faced with those conflicts, which are generated in the City, the government implemented different strategies and concepts, including its great political project that "the city is in very good condition." Or, as the head of government mentioned: "We are going to take a great investment stretch so that the city is well paved, that the benches are well worked. I want to change the image to Mexico City. Leave a pretty city ${ }^{1}$. "For that reason his work has been incessant in the projection of a new idealized image based on various elements that are made visible in the public space and that emphasize the sense of belonging and social identity of a city / society, projecting towards the future through a democratic, conciliatory and plural discourse.

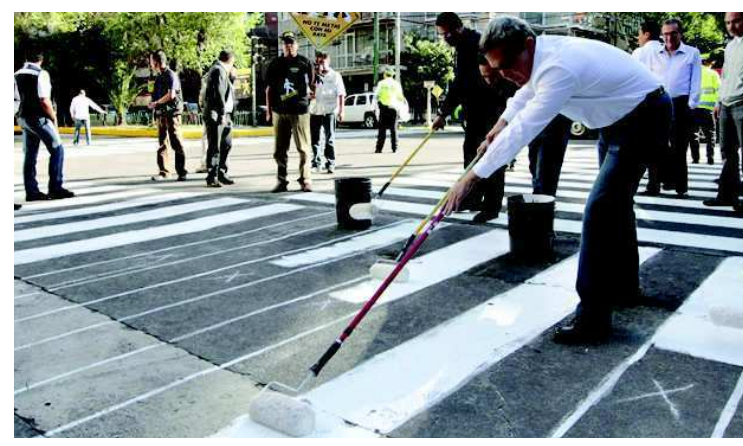

In this idealized projection of a city and a claim to identity, integration and law, the public space of the city is re-emerging in different urban policies and programs that seek to reduce socio-spatial inequalities strengthen community identity and rehabilitate the social fabric. "At the same time that it promotes the shared participation of neighbors and public servants to improve the public spaces that allow to streng then the Social Capital that the capital deserves". Among the different programs are: "First the Pedestrian", "Streets for All", "Your City Re-Want", "Safe Steps", "Ecoparq", "Pocket Parks", "King Pedestrian" and "Under Bridges". For example, the program "Your City Wants You ": "aims at citizen participation in the improvement and conservation of public space and community relations" 3 . Its objectives are to strengthen collaboration between the population and the authorities, through actions to clean up and restore public spaces and to contribute with small-scale actions to the improvement of neighborhood coexistence, community identity and the recovery of values such as respect, tolerance And civics, contributing to sustainability, urban aesthetics, respect, cohesion and the re-composition of the social tissue ". This program was especially highlighted, since it was widely propagated by the media an image in which the head of government appeared painting the zebras of the streets as part of this program".

Some issues arise from this program. For example, why did the painting of pedestrian zebras become public works and a government project? If the government offered municipal

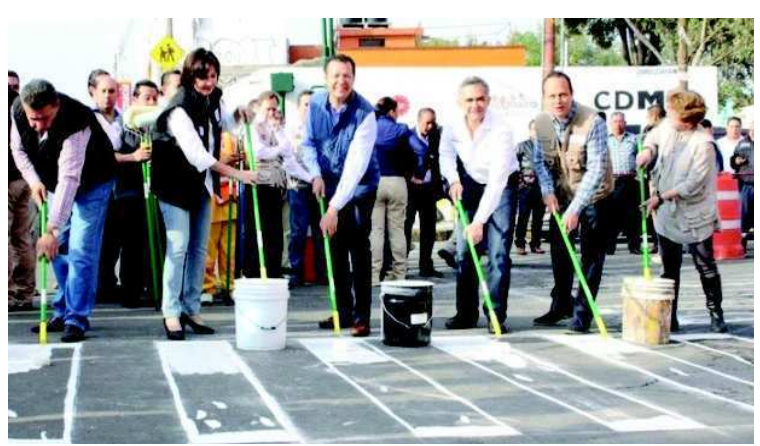

Figure 2.

a. (left) The head of the capital government painting a pedestrian zebra. Source: http:// mexicoparalosmexicanos.blogspot.mx/2015_09_01_archive.html. b. (right) The head of the capital government painting a pedestrian zebra. Source: https://ciudadpedestre.wordpress.com/2014/08/18/ el-jefe-de-gobierno-pinta-y-luego-cruza-un-paso-de-cebra/ 
Figure 3.

The head of the capital government posing for a photo after a zebra painted as the cover of Abbey Road by the Beatles.

Source: https://ciudadpedestre. wordpress.com $/ 2014 / 08 / 18 /$ el-jefede-gobierno-pinta-y-luego-cruza-unpaso-de-cebra/

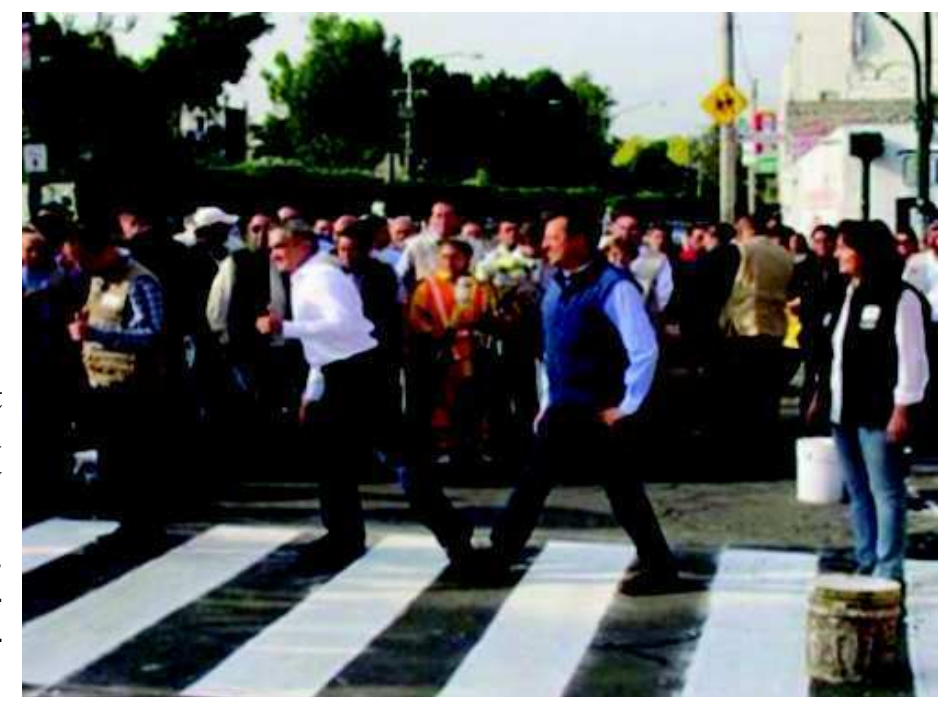

public services that are part of its attributions and responsibilities whose legal basis is found in the Political Constitution of the United Mexican States, which defines the areas in which the municipality is responsible for the care according to article $115^{5}$. Would it be necessary to do as much media as painting zebras? Even, would there be the need to pose for a photo as a tourist postcard (Figure 3)?

This shows, on the one hand, a complete ignorance of the city by the authorities, but, on the other hand, the inability of the government to solve the real problems, seeking to dissuade its responsibilities through the spectacle and the mediatization of interventions Which in no way contribute to the quality of life of the inhabitants of a city where 28.9 percent of the inhabitants live in poverty according to the Human Rights Commission of Mexico City.

This type of action, once again, serves to conceal works of impact (such as large road infrastructure), which go against the same discourses of social integration, even because they have a differentiated territorial distribution in the city, What is done is not for everyone, nor in the same way. Why are these kinds of differentiated manifestations made? What do these types of interventions respond to? This type of actions is reproduced in a contradictory way in the city, such as "Under Bridges", which focuses on the residual spaces generated by the construction of vehicular bridges in Mexico City, aiming to convert them into interconnection points: "The scheme of operation of the low bridges is 50 percent of public space, 30 percent of commercial area built and 20 percent of free area that is used as free or controlled parking." However, there have been several criticisms of this program, since it has become a government business that has led to the privatization of public space, by concessions to commercial renters, which makes them tertiary spaces of services and commerce.

However, the program that has undoubtedly had the most impact in political-media terms, and which has been part of the speech of the capital government even as part of its electoral campaign, have been "Pocket Parks." This is a program that consists of: "the recovery of urban spaces and roads that are either remnants or underutilized, to convert them into areas for community enjoyment, in addition to generating positive impacts on mobility, promoting pedestrianization of spaces and The universal accessibility, as well as an improvement in the environmental quality, the urban image and the integration of the social tissue"

Pocket parks have become part of a discourse that legitimizes intervention by a "fictional" interventionist government and conscious of its arbitrariness because "in any society the production of discourse is at the same time controlled, selected and redistributed by a certain number of Procedures that have as function to conjure the powers and dangers, to dominate the random event and to dodge its heavy and fearsome materiality "(Foucault, 2014). 

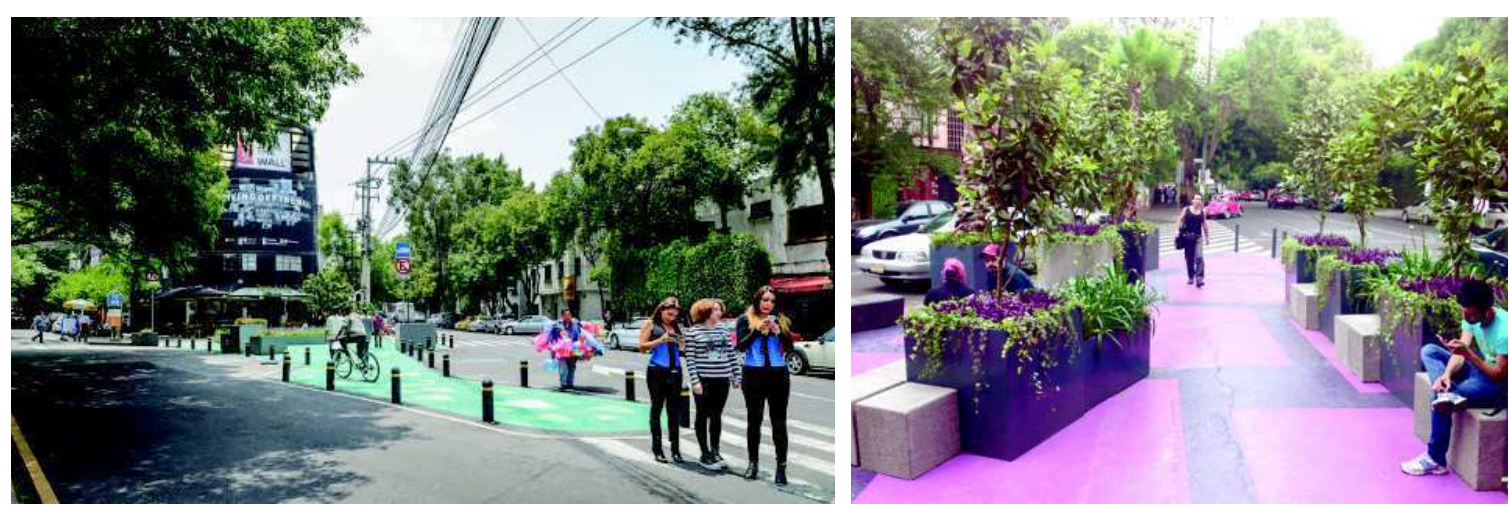

Figure 4.

Pocket Park Examples.

Source: http://www.verdmx.org/proyectos/parques-de-bolsillo/

It should be noted that all these programs are managed, implemented and administered, either wholly or in part, by the Public Space Authority (AEP). This organization was created in 2008 thanks to the then head of the capital government, Marcelo Ebrard. The AEP is a decentralized body of the Ministry of Urban Development and Housing of the Government of Mexico City, which has gained more attention today, and it can be said that it is the main organ that intervenes and manages the public space. Its objective, according to the governmental discourse of the AEP, is: "to promote initiatives for the urban environment and that translate into the active construction of the social space for urban identity; develop emblematic rescue projects that could trigger an improvement in the quality of life of the inhabitants; and the creation of these spaces, is fulfilled with another of the concerns of the

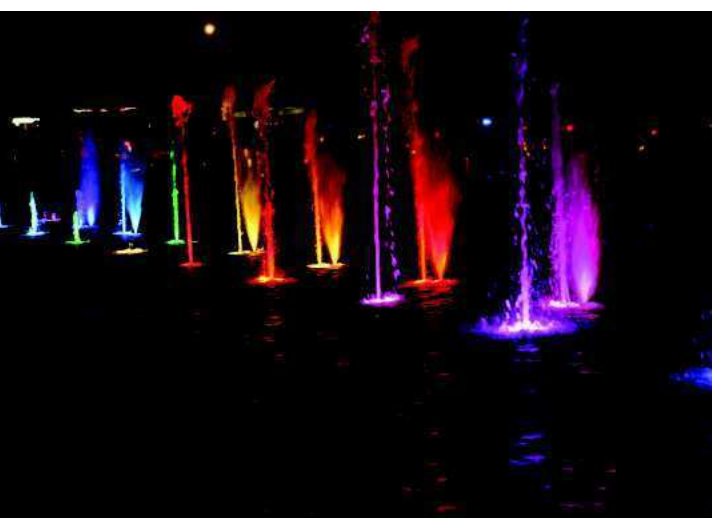

citizens, expressed in Decisions for Cologne, in order to make Mexico City a livable and friendly place ${ }^{6 "}$.

These interventions are projected into a discursive framework that are assembled in interventions that do not really bring anything new, but rather are discourses that reproduce transversely to different governments in Mexico (Narciso, 2014). Interestingly, however, these interventions are concentrated in the profitable urban areas of the middle and upper classes, as can be seen in the maps (Figure 6).

Clearly the public space has gained a greater "attention" on the part of the current capital government, since the number of interventions has increased. Nevertheless, an unequal sociospatial distribution can be observed, since the majority of the interventions have been carried out in the delegations Miguel Hidalgo and Cuauhtémoc, in the latter especially in

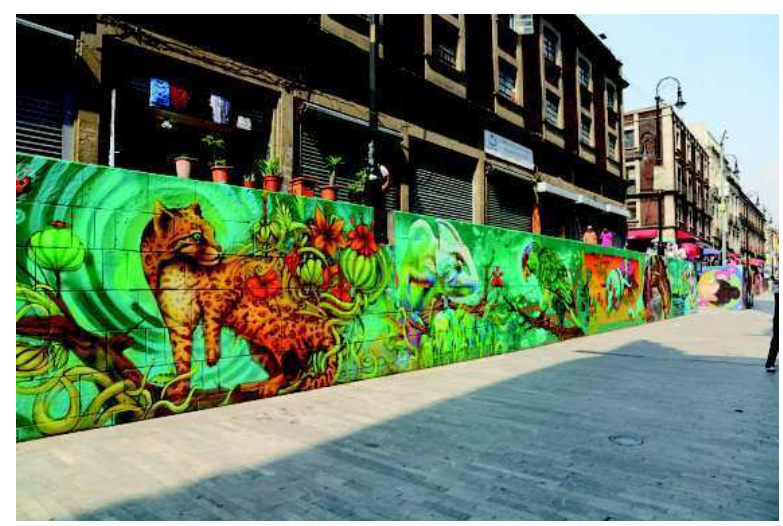

Figure 5.

Interventions of the Public Space Authority. a. (left) Walk of the composers - 2nd section Chapultepec. Miguel Hidalgo. b. (right) Historical Center. Source: Public Space Authority 

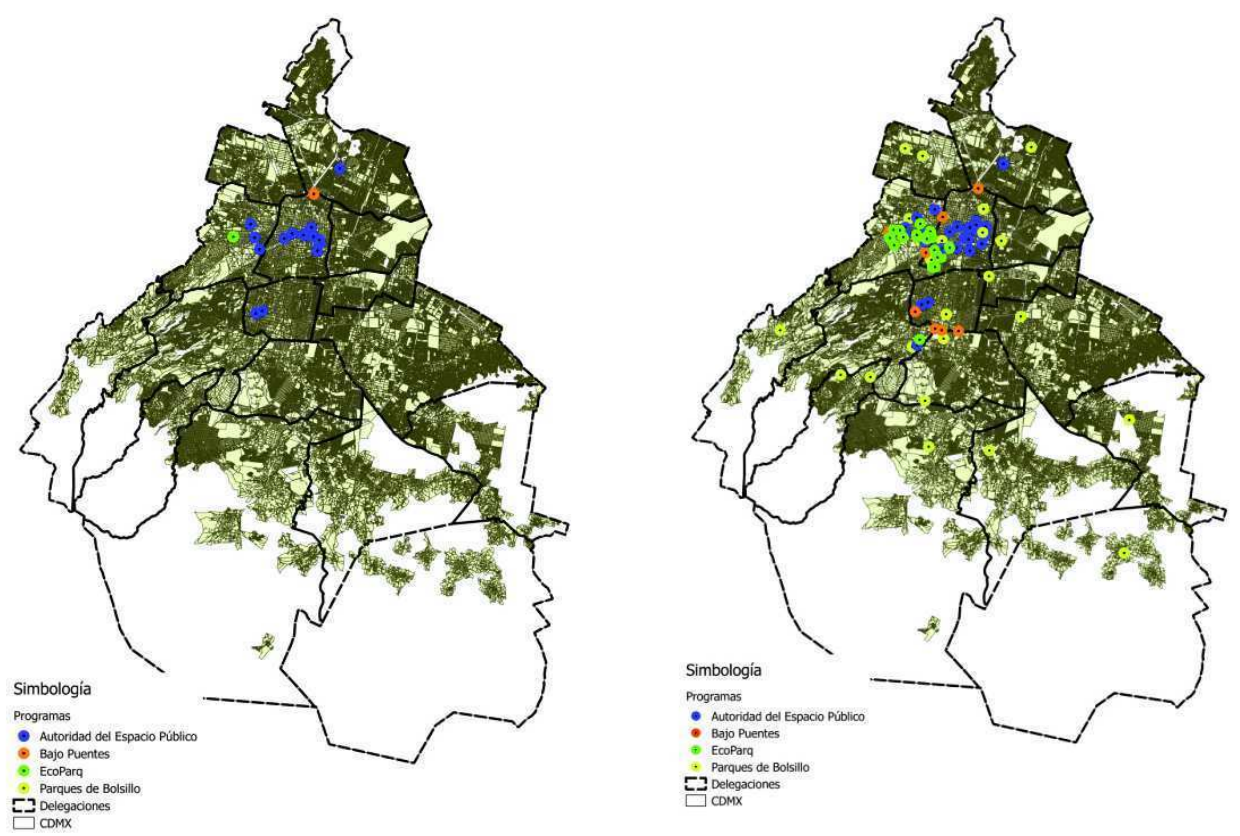

Figure 6.

a. (left) Interventions in the Government of Marcelo Ebrard.

b. (right) Interventions in the Government of Miguel Angel Mancera. Source: Produced by Rubi Estrada.

the colonies Roma, Condesa and Hipódromo, just in the Delegations and colonies where the floor area is among the highest in the City. For its part, what we can observe is a timely distribution of pocket-sized parks, which leads us to question: how is it possible that in the Iztapalapa delegation, with a population of almost 1900000 inhabitants, has been carried out A single intervention of a pocket park? In that sense, what are these programs responding to? Why this unequal distribution of interventions and public resources?

\section{Some Reflections to Re-think the Public Space}

Symbolically, public space hides a series of ideologies that have transformed it into a decorative element but, above all, an element of domination and social control that translates into demagogic discourses, which provoke the illusion that what is done is for The social integration, appealing to the rights that each one owns. For this reason, in the pre-eminent speech of defense of the poor and rescue of the social fabric, as a human right, public space has topped the political agenda, and is anchored in a cultural framework of ideological social salvation that does nothing more than follow Reproducing a status quo, which widens the gap between social classes.

This type of intervention consists of a way of reinventing the city as part of the neoliberal model linked to two ideological purposes: on the one hand, the insertion in a global framework of cities by the need to attract and maintain a more than adequate elite (Massey, 2008) and on the other hand, the domestication and control of popular sectors through the imposition of space-time forms that oppresses reality in myths constructed and represented through cultural scales. Urban space has become a material extension of what in reality is ideology, in the classical Marxist sense, that is, masking or fetishization of real social relations and presents the same will that every ideology shares in existence as an object (Delgado, 2011: 29). Governments start from the social function of ideology as the set of beliefs and ideas or representations that stimulate and foster cohesion and identity among members of a social group to exercise, as the case may be, a domain or active subordination between 
The remaining groups of society (Karp, 1988), but what they do, in fact, is to increase social inequalities and social fragmentation. Thus, public space becomes an ideological device of social control and capitalist accumulation because, as Foucault (1980) points out, in any society there are manifest relations of power that permeate, characterize and constitute the social body, and these relations of power can't be established, consolidated or implemented without the production, accumulation and operation of a discourse. However, what are generated are a symbolic violence and the construction of illusions towards the lowerincome classes.

\section{Notes}

1 Interview with Forbes magazine, "The Alpha City of Miguel Angel Mancera”, Mexico, April 20, 2013.

2 This program began with the government of Marcelo Ebrard, but has acquired greater importance in the current government.

3 Taken from: http://www.excelsior.com. $\mathrm{mx} /$ comunidad/2013/06/08/902998.

4 Taken from: http://www.excelsior.com. mx/comunidad/2013/06/08/902998.

5 Guide to municipal public services, National Institute for Federalism and Municipal Development, Ministry of Interior.

6 Public Space Authority.

\section{References}

Brenner, N.; Peck, J.; Theodore, N. (2009). Urbanismo neoliberal: La ciudad y el imperio de los mercados. SUR Corporación de Estudios Sociales y Educación, Temas sociales, n. 66 .

Delgado, M. (2011). El espacio público como ideología. Madrid: Catarata.

Foucault, M. (1980). Power Knowledge: Selected interviews and writings 1972-1977. New York: Pantheon Books.

Harvey, D. (1990). The Condition of Postmodernity. An Enquiry into the origins of Culture Change. Oxford: Basil Blackwell.

Karp, L. (1988). El proceso de las formaciones ideológicas. Morelos: Crim.

Leitner, H. \& Sheppard, E. (1998) Economic uncertainty, inter-urban competition and the efficacy of entrepreneurialism. En T. Hall \& P. Hubbard (eds.). The Entrepreneurial City. Chichester: Wiley, 285-308.

Massey, D. (2008). Pelo espaço. Brasil: Bertrand.

Narciso, C. (2014). ¿Cuál Espacio Público? Los lugares de uso, consumo y diferenciación social en la Ciudad de Cuernavaca. Tesis de Doctorado en Urbanismo, México, Universidad Nacional Autónoma de México, Facultad de Arquitectura, Posgrado en Urbanismo.

Parnreiter, C. (2015). Las ciudades latinoamericanas en la economía mundial: la geografía de centralidad económica y sus transformaciones recientes. Economiaunam, vol.12, Núm.35.

Peck, J. \& Tickell, A. (1994) Searching for a new institutional fix: The after-Fordist crisisand global-local disorder. En A. Amin (ed.) PostFordism: A Reader. Oxford: Blackwell, 280-315.

Pradilla, E. (2009) Los territorios del neoliberalismo en América Latina (Universidad Autónoma de México/Miguel Ángel Porrúa, México).

Swyngedouw, E. (1992) The Mammon quest: 'Glocalisation', interspatial competition and the monetary order: The construction of new scales. En M. Dunford \& G. Kafkalas (eds.). Cities and Regions in the New Europe London: Belhaven Press, 39-62. 